\title{
Quo vadis, taxonomy of cyanobacteria (2019)
}

\author{
Jiří KOMÁREK
}

Faculty of Science, University of South Bohemia, Branišovská 31, CZ 37005 České Budějovice, Czech Republic

\begin{abstract}
Motto: "I consider the human endeavour to discover new processes and regularities in nature, completed by requirement and satisfaction in logical arrangement of discovered facts into the objective and regular order, as a main stimulus of the noble evolution of the human society." - Albert Einstein.

Abstract: The problem of identification and evaluation of new described cyanobacterial taxa, particularly of the genera established after molecular sequencing, is discussed. Numerous new taxonomic units were defined according to molecular analyses in the last 20 years, but their later identification by biological community (particularly by ecologists) is often hardly possible. The molecular sequencing and evaluation must be surely a basis of the modern and future taxonomic classification, but the application of polyphasic approach to the definition of single taxa and enabling the orientation and later recognition of all described taxonomic units is quite necessary and inevitable.
\end{abstract}

Key words: cyanobacteria, taxonomy, morphology, traditional evaluation, molecular sequencing, polyphasic approach

The taxonomy of prokaryotic cyanobacteria was traditionally based on cytomorphological and ecological markers, similarly as of other groups of simplest phototrophic, unicellular algal, eukaryotic organisms (phytoflagellates, coccal algae, etc.). Cyanobacteria were originally called "blue-green algae" in respect to their morphological similarity to simple algae and their morphology and ecological diversity. The substantial changes in their nomenclature and terminology started with the clear recognition and statement of their phylogenetic bacterial origin and prokaryotic (bacterial) structure of cells. The name "blue-green algae" was uncompromisingly changed in "cyanobacteria" and this term was commonly accepted by scientific community over the world for the designation of this special group of phototrophic microorganisms (cf. RIPPKA et al. 1979; RIPPKA \& COHEN-BAZIRE 1983; etc.).

The next, very important progress in this field was the introduction of genetic methods, mainly the molecular sequencing, to the study of organismal populations. The great amount of studies in several last years appeared, based on sequencing of numerous isolated strains of cyanobacteria. The result of this progress in taxonomic studies was creation and definition of many new cyanobacterial genera, based exclusively on their isolated or separated positions in phylogenetic trees (in many cases as cryptogenera). The present review of cyanobacteria is now therefore unfortunately confused and unclear, and relations between different published taxa on the generic and specific levels are undefinable and undeterminable.

Of course, the determination of the genetic relations must be the basis of the correct classification of cyanobacteria (and all organisms) and the modern method of molecular sequencing of cyanobacteria must be accepted as the evident and obvious method and basis of their taxonomic organization. However, they exist several not yet solved problems in new introduced methods:

- The authors evaluate recently arbitrary selected cultured strains by molecular methods (sequencing) without their comparison with the common (and often precisely described) natural populations.

- Their results are surely phylogenetically correct, but among the used strains lack lot of other related strains and described species, and the results are therefore incomplete.

- The different authors use the different strains to their analyses and usually also the various materials, and their results are not reciprocally comparable.

- Almost in all traditional genera, described before 2000 , is usually impossible to sequence the type material. Therefore are used the later isolated strains to molecular treatments. It does not exist usually any proof that the strains correspond really to the designated type species of the traditional and/or 
compared studied genera and species. (At least, the later selected strains should correspond to the diagnoses - descriptions of corresponding types as much as possible.)

- Many authors use to their conclusions the traditional nomenclature in different degree, but the correctness of several used names is questionable. The authors use usually the names, by which were the experimental strains designated by their isolators, although their identification was based often only on the provisory marking of the isolating author, according to the superficial morphological observation. It is even difficult to say, if the used strains represent really the corresponding traditional species, which are marked on the label of the compared taxon. The comparison with the characters of the type species of the cited higher taxon is usually lacking and the majority of results are therefore problematic. The strains can be incorrectly identified and almost never are controlled.

- The all taxa (families, genera, species) must be based on the types. The modern authors usually designate the type species in new described genera, but it is based only on one type strain, without wider characteristics of the whole species. The comparison of diacritical features with characters of the type species of related, traditional and compared species is usually lacking.

- When the authors revise the traditional, sooner described genera, they usually use only one selected (or few) later strain from the whole genus. In most important traditional genera never are included and compared all species, described (according to morphology and ecology) as members of the whole higher taxon - genus.

- The position of the originally described compared genera remains always unclear and the characters of all up to now published species are incomplete and quite insufficient. In spite of it, the authors combine often automatically all described species into the new revised genus without their knowledge.

- Taxa, from which does not exist any isolated strain, have no chance to be revised.

- In published new genera are presented explicitly only exceptionally markers, according to which is possible to recognize the new established units, following from molecular sequencing, by the later users and researchers. Usually are not presented the diacritical features (and sometime also ecological characteristics) of all species of the whole revised genus (traditional or new).

- The new established generic entities remain solitary, without any knowledge, if other up to date described species belong to the same phylogenetic line, and also without possibility to organize the new defined taxa into the whole system and order. From 2000, more than 140 new genera were defined, mainly according to genetic criteria, but often without classification into the existing (or any new) system.

- The natural material (populations) and important ecology of species are usually quite omitted in such studies. However, the system of cyanobacteria must be usable also for field ecological and pedagogical studies.

- Several authors ignore the majority of nomenclatural rules, which are obligatory and mandatory for description of new taxa (particularly genera and species). It is, e.g., the main disadvantage of the study of WALTER et al. (2017), who designate invalidly 33 new genera and 28 new species only on the basis of genomic analysis, without descriptions and typification.

The result of this practice is that we have now lot of new genera and species, the identification of which is almost impossible without repeating of the same molecular method and the same strains, as were used by the original author. Only the position in the phylogenetic tree is insufficient for taxonomy and later identification. It is therefore usually impossible to compare such new taxa (strains and populations) with the traditional system and to identify them.

A good example of new described cryptogenera are, e.g., the unicellular Crocosphaera, Zehria and Rippkaea (MAREŠ et al. 2019). The cells of these genera (described from cultured strains, with about 8 defined units on the species level) are cytomorphologically very similar and differ only slightly in position in authors' phylogenetic tree. The strains were isolated only from two habitats, marine/oceanic littoral and rice fields. If you find similar population in nature, you have no chance to find any diacritical character and to identify even its generic position.

From this situation follows also the existence of various groups of incomparable and not identifiable cyanobacterial taxa in literature. One is identical with the traditional classification, based on the old morphological criteria (which is commonly used for identification, but evidently already outdated and not in agreement with correct evolutionary trends) and, on the other hand, the heterogeneous agglomeration of new defined taxa, supported by their molecular position, but without possibility to organize them in a logical system (not later identifiable and comparable with the commonly known traditional taxa). This hopelessness results from the necessity to register and classify the whole known diversity of the cyanobacterial group. The situation is complicated by the common use of all old traditional names and nomenclatural rules, which are arbitrarily used also in modern studies, and what overfill the present cyanobacterial system by not determinable, not recognizable and not comparable taxa.

On the contrary, other conclusion, following from molecular analyses, is the unification of very similar and genetically unique (very related) groups, which differ by one or few, but important qualitative feature (e.g., 
presence or absence of any important character, characteristical part of the life cycle, etc.), which are, however, important from the diversification point of view. They do not exist directives or prescription of evaluation of such distinct differences, which were used as diacritical features between taxa. Example is the case of the genera Cylindrospermopsis and Raphidiopsis, which differ by the obligatory presence or absence of heterocytes (also after cultivation with or without nitrogen) (AGUILERA et al. 2018). The authors sequenced two own isolated later strains of the type species $R$. mediterranea (but not isolated from type material), compared them with a wide set of other strains of Cylindrospermopsis raciborskii (type species, but not type material) and Raphidiopsis from previous studies, and concluded that after $16 \mathrm{~S}-23 \mathrm{~S}$ ITS and cpcBA-16S sequences are these two genera virtually identical. In spite that they did not studied the type material, that just the statistical limit of less as $30 \%$ is quite artificial, that they differ in presence/absence of the phylogenetically important qualitative feature (ability to form heterocytes) and that other (about 15) described and morphologically very characteristical species from the genus Cylindrospermopsis were not studied.

WALTER et al. (2017) published a modern study "Ecogenomics and taxonomy of cyanobacteria phylum" based on the precise analysis of cyanobacterial genomes of more than one hundred strains, with fascinating table with 33 proposals of new generic and 87 proposals of specific names. Moreover, they use 4 traditional cyanobacterial generic names with content, different from the originally defined taxa. However, all these "new" taxa are not described respecting nomenclatural rules and concern only solitary strains. It is difficult to expect that somebody would be able to identify any cyanobacterial population from nature (or new isolated strain) according to this scheme. In spite of it, the authors "strongly recommend that the modern cyanobacterial taxonomy should be based on WGS" (whole genomic sequencing). It is surely the very sophisticated proposal, but the reorganization of the whole cyanobacterial taxonomy is at present hardly possible by this way. Firstly, it should be useful to publish methodology of the transfer of the whole up to now known cyanobacterial diversity into this new cyanobacteria genomic taxonomy system (CGT). System, which enables also to identify taxonomy of all natural populations of "water blooms" from eutrophised localities, populations from extreme habitats, wetted stony walls, soils etc.

It is necessary to find therefore the methodological guide, leading to the possibility to organize the modern completed cyanobacterial system, in which the genetic relations (genomic characters) will be the basis, but obligatory completed with all other stable markers, which must be also respected. This system, based on polyphasic approach must enable the orientation and determination of all cyanobacteria (sooner described or new defined) occurring in natural ecosystems, as well as isolated strains (which can change often their properties and features after long cultivation under stable culture conditions). It means therefore that it must be applied consistently the polyphasic approach with the phylogenetic classification as the basis, but with the convenient combination and addition of all cytomorphological and ecological important data and with the adequate use of nomenclature prescriptions.

Of course, we are not able to propose a convenient method of classification, which can change at once this situation. However, we have tried to summarize all the new validly described cyanobacterial genera, completed by documented cytomorphological characters and prepared the review of the modern cyanobacterial system, based on modern, mainly molecular methods combined with old (presented) common criteria. In this list are included almost all genera described after 2000 (more than 140, but without 33 proposals of WALTER et al. 2017), in which was possible to find other features, important for polyphasic evaluation (Tab. 1 in appendix). However, the identification and characterization of new populations, corresponding to these taxa is impossible without complicated molecular procedures copying the used strains from the original authors. If we intend to modernize the necessary system usable for the all progress in the science, for the later users and for any determination, this system must be radically revised and accomplished. The method leading to the simple identification of new defined taxa is quite necessary for ecology. It is impossible to wait on the situation, when all related laboratories will use corresponding easy molecular procedures, enabling the identification of all taxa.

The possible way for improvement of this situation would be the obligatory observing and keeping of the nomenclatural rules prescribed for the publishing of new taxa of cyanobacteria. And also a slight modification of nomenclatural rules for description of new cyanobacterial taxa: All new diagnoses of cyanobacteria must describe the genetic position (at least the comparison with most related taxa), but include also the markers, according to which is possible to identify and recognize the described taxa (not only strains) and must be placed into the existing modern system on the level of species, genus and family. All taxa published without this information must be considered as invalid and should be supplied subsequently by this information (validated). The authors should elaborate also obligatory proposal of a key, containing their new taxa and enabling their later identification. Cryptogenera and cryptospecies must be described in connection (compared or attached) to the oldest name of most related generic/specific taxon. All results without these data are invalid and cannot be accepted and included in any cyanobacterial system.

\section{REFERENCES}

To the conclusions of this short article was used wide cyanobacterial literature. In the following list are included 
only the papers, which can be particularly important for the next solution of this problem. However, many other citations must be used for future work in this field.

Abed, R.M.M.; Garcia-Pichel, F. \& Hernández-Mariné, M. (2002): Polyphasic characterization of benthic, moderately halophilic, moderately thermophilic cyanobacteria with very thin trichomes and the proposal of Halomicronema excentricum gen. nov., sp. nov. Archives of Microbiology 177: 361-370.

ANAGNOSTIDIS, K. \& KomÁREK, J. (1988): Modern approach to the classification system of cyanophytes. 3. Oscillatoriales. - Algological Studies 80: 327-472

Anagnostidis, K. (2001): Nomenclatural changes in cyanoprokaryotic order Oscillatoriales. -Preslia 73: 359-375.

Aguilera, A.; Gómez, E.B.; KAŠTovskŕ, J.; EcheniQue, R.O. \& SAlERNo, G.L. (2018): The polyphasic analysis of two native Raphidiopsis isolates supports the unification of the genera Raphidiopsis and Cylindrospermopsis (Nostocales, Cyanobacteria). - Phycologia 57: 130-146.

Becerra-Absalón, I.; Johansen, J.R.; Muñoz-Martín, M.A. \& Montejano, G. (2018): Chroakolemma gen. nov. (Leptolyngbyaceae, Cyanobacteria) from soil biocrusts in the semi-desert Central Region of Mexico. - Phytotaxa 367: 201-218.

BOYER, S.L.; FleChTNER, V.R. \& JOHANSEN, J.R. (2001): Is the 16S-23S rRNA Internal Transcribed Spacer Region a Good Tool for Use in Molecular Systematics and Population Genetics? A Case Study in Cyanobacteria. - Molecular Biology and Evolution 18:1057-1069.

Brito, A.; Ramos, V.; Mota, R.; Lima, S.; SAntos, A.; Vieira, J.; VieIRA, C.; KAŠTOVSKÝ, J.; VASCONCELOS, V.M. \& TAMAgnini, P. (2017): Description of new genera and species of marine cyanobacteria from the Portuguese Atlantic coast. - Molecular Phylogenetics and Evolution 111: 18-34.

Brito, Â.; Ramos, V.; Seabra, R.; Santos, A.; Santos, C.L.; Lopo, M.; Ferreira, S.; Martins, A.; Mota, R.; Frazao, B.; Martins, R.; Vasconcelos, V. \& Tamagnini, P. (2012): Culture-dependent characterization of cyanobacterial diversity in the intertidal zones of the Portuguese coast: a polyphasic study. - Systematic and Applied Microbiology 35: 110-119.

Caires, T,A.; Lyra, G. DE M.; Hentschke, G.S.; Silva, A.M.S. DA; AraúJo, V.L. DE; Sant'AnNa, C.L. \& Nunes, J.M. DE C. (2018): Polyphasic delimitation of a filamentous marine genus, Capillus gen. nov. (Cyanobacteria, Oscillatoriaceae) with the description of two Brazilian species. - Algae 33: 291-304.

Caires, T.A.; Lyra, G.M.; HentschKe, G.S.; Pedrini, A.G.; SANT'ANNA, C.L. \& Nunes, J.M.C. (2018): Neolyngbya gen. nov. (Cyanobacteria, Oscillatoriaceae): A new filamentous benthic marine taxon widely distributed along the Brazilian coast. - Molecular Phylogenetics and Evolution 120: 196-211.

Casamatta, D.A.; Johansen J.R.; Vis, M.L. \& Broadwater S.T. (2005): Molecular and morphological characterization of ten polar and near-polar strains within the Oscillatoriales (Cyanobacteria). - Journal of Phycology 41: 421-438.

Casamatta, D.; Vis, M.L. \& Sheath, R. (2003): Cryptic species in cyanobacterial systematics: a case study of Phormidium retzii (Oscillatoriales) using RAPD molecular markers and 16S rDNA sequence data. Aquatic Botany 77: 295-309.
Casamatta, D.; Stanic, D.; Gantar, M. \& Richardson, L.L. (2012): Characterization of Roseofilum reptotaenium (Oscillatoriales, Cyanobacteria) gen. et sp. nov. isolated from Caribbean black band disease. - Phycologia 51: 489-499.

Dadheech, P.K.; Mahmoud, H.; Kotut, K. \& Krienitz L. (2012): Haloleptolyngbya alcalis gen. et sp. nov., a new filamentous cyanobacterium from the soda lake Nakuru, Kenya. - Hydrobiologia 691: 269-283.

DadheECh, P.K.; Abed, R.M.M.; Mahmoud, H.; Mohan, M.K. \& KrienitZ, L. (2012): Polyphasic characterization of cyanobacteria isolated from desert crusts, and the description of Desertifilum tharense gen. et sp. nov. (Oscillatoriales). - Phycologia 51: 260-270.

DvoŘÁk, P.; HašLER, P.; Pitelková, P.; TABÁKová, P.; CASAMATTA, D.A. \& PoulíčKová, A. (2017): A new cyanobacterium from the Everglades, Florida - Chamaethrix gen. nov. - Fottea 17: 269-276.

Dvořák, P.; Hindák, F.; HašLer, P.; HindÁková, A. \& PoulíčKovÁ, A. (2014): Morphological and molecular studies of Neosynechococcus sphagnicola, gen. et sp. nov. (Cyanobacteria, Synechococcales). - Phytotaxa 170: 24-34.

DvoŘÁK, P.; JAHODÁŘové, E.; HAŠLER, P.; GuSEv, E. \& PoulíčKová, A. (2015): A new tropical cyanobacterium Pinocchia polymorpha gen. et sp. nov. derived from the genus Pseudanabaena. - Fottea 15: 113-120.

Engene, N.; Paul, V.J.; Byrum, T.; Gerwick, W.H.; Thor, A. \& ElLisman, M.H. (2013): Five chemically rich species of tropical marine cyanobacteria of the genus Okeania gen. nov. (Oscillatoriales, Cyanoprokaryota). - Journal of Phycology 49: 1095-1106.

Engene, N.; Tronholm, A.; SAlvador-Reyes, L.A.; Luesch, H. \& Paul, V.J. (2015): Caldora penicillata gen nov., sp. nov. (Cyanobacteria), a pantropical marine species with biomedical relevance. - Journal of Phycology 51: 670-681.

Engene, N.; Tronholm, A. \& Paul, V.J. (2018): Uncovering cryptic diversity of Lyngbya: the new tropical marine cyanobacterial genus Dapis (Oscillatoriales). - Journal of Phycology 54: 435-446.

ERWIN, P.E. \& THACKeR, R.W. (2008): Cryptic diversity of the symbiotic cyanobacterium Synechococcus spongiarum among sponge hosts. - Molecular Ecology 17: 2937-2947.

Fiore, M.F.; SAnt'Anna, C.L.; Azevedo, M. T.; KomáReK, J.; KAŠTovsKÝ, J.; SULEK, J. \& LoRENZI, A.S. (2007): The cyanobacterial genus Brasilonema, gen. nov., a molecular and phenotypic evaluation . - Journal of Phycology 43: 789-798.

Furtado, A.L.F.F.; do Carmo CaliJuri, M.; Lorenzi, A.S.; Honda, R.Y.; GenuÁrio, D.B. \& Fiore, M.F. (2009): Morphological and molecular characterization of cyanobacteria from a Brazilian facultative wastewater stabilization pond and evaluation of microcystin production. - Hydrobiologia 627: 195-209.

Gomont, M. (1892): Monographie des Oscillariées (Nostocacées homocystées). - Annales des Sciences Naturelles, Botanique, Série 7 15: 263-368.

Hašler, P.; Dvořák, P.; PoulíčKová, A. \& Casamatta, D.A. (2014): A novel genus Ammassolinea gen. nov. (Cyanobacteria) isolated from subtropical epipelic habitats. - Fottea 14: 241-248.

HeidARI, F.; Zima, J.; Riahi, H. \& HaUER, T. (2018): New simple trichal cyanobacterial taxa isolated from radioactive 
thermal springs. - Fottea 18: 137-149.

LÜCKInG, R.; BARRIE, F.R. \& GENneY, D. (2014): Dictyonema coppinsii, a new name for the European species known as Dictyonema interruptum (Basidiomycota: Agaricales: Hygrophoraceae), with a validation of its photobiont Rhizonema (Cyanoprokariota: Nostocales: Rhizonemataceae). - The Lichenologist 46: 261-267.

Iteman, I.; Rippka, R.; Tandeau de Marsac, N. \& Herdman, M. (2002): rDNA analyses of planktonic heterocystous cyanobacteria, including members of the genera Anabaenopsis and Cyanospira. - Microbiology 148: 481-496.

JAHODÁŘOvÁ, E.; DVOŘÁK, P.; HAšLER, P.; HoluŠOvÁ, K. \& PoulíčKovÁ, A. (2018): Elainella gen. nov.: a new tropical cyanobacterium characterized using a complex genomic approach. - European Journal of Phycology 53: 39-51.

JAHODÁŘová, E.; DvořÁK, P.; HAŠLER, P. \& PoulíčKovÁ, A. (2017): Revealing hidden diversity among tropical cyanobacteria: the new genus Onodrimia (Synechococcales, Cyanobacteria) described using the polyphasic approach. - Phytotaxa 326: 28-40.

Johansen, J.R. \& Casamatta, D.A. (2005): Recognizing cyanobacterial diversity through adoption of a new species paradigm. - Algological Studies 117: 71-93.

Johansen, J.R.; Olsen, C.E.; Lowe, R.L.; FučíKová, K. \& CASAMATTA, D.A. (2008): Leptolyngbya species from selected seep walls in the Great Smoky Mountains National Park. - Algological Studies 126: 21-36.

Johansen, J.R.; KovéčIK, L.; CASAMATta, D.A.; FuČÍIKovÁ, K. \& KAŠTOVSKÝ, J. (2011): Utility of 16S-23S ITS sequence and secondary structure for recognition of intrageneric and intergeneric limits within cyanobacterial taxa: Leptolyngbya corticola sp. nov. (Pseudanabaenaceae, Cyanobacteria). - Nova Hedwigia 92: 283-302.

JohANSEn, J.R.; BohunickÁ, M.; LuKešová, A.; HrČKovÁ, K.; VACCARINO, M.A. \& Chesarino, N.M. (2014): Morphological and molecular characterization within 26 strains of the genus Cylindrospermum (Nostocaceae, Cyanobacteria), with descriptions of three new species. - Journal of Phycology 50: 187-202.

KIM, M.; OH, H.-S.; PARK, S.-C. \& ChUn, J. (2014): Towards a taxonomic coherence between average nucleotide identity and 16S rRNA gene sequence similarity for species demarcation of prokaryotes. - International Journal of Systematic and Evolutionary Microbiology 64: 346-351

KomáReK, J. (2016): A polyphasic approach for the taxonomy of cyanobacteria: principles and applications. - European Journal of Phycology 51: 346-353.

KomÁreK, J. (2018): Several problems of the polyphasic approach in the modern cyanobacterial system. Hydrobiologia 811: 7-17.

KomÁreK, J. \& AnAGnostidis, K. (2005): Cyanoprokaryota -2. Teil/ 2nd Part: Oscillatoriales. - In: BÜDEL, B.; Krienitz, L.; Gärtner, G. \& Schagerl, M. (eds): Süsswasserflora von Mitteleuropa, vol. 19/2. - 759 pp., Elsevier/Spektrum, Heidelberg.

KomÁReK, J.; KopeckÝ, J. \& CEPÁK, V. (1999): Generic characters of the simplest cyanoprokaryotes Cyanobium, Cyanobacterium and Synechococcus. - Cryptogamie Algologie 20: 209-222.

KomáreK, J.; KaštovskÝ, J.; Mareš, J. \& Johansen, J.R. (2014): Taxonomic classification of cyanoprokaryotes (cyanobacterial genera) 2014, using a polyphasic approach - Preslia 86: 295-335.

KomáreK, J.; KaštovskÝ, J.; Ventura, S.; Turicchia, S. \& Śmarda, J. (2009): The cyanobacterial genus Phormidesmis. - Algological Studies 129: 41-59.

Korelusová, J.; KašTovskÝ, J. \& KomÁreK, J. (2009): Heterogeneity of the cyanobacterial genus Synechocystis and description of a new genus, Geminocystis. - Journal of Phycology 45: 928-937.

Lepère, C.; Wilmotte, A. \& Meyer, B. (2000): Molecular Diversity of Microcystis Strains (Cyanophyceae, Chroococcales) Based on 16S rDNA Sequences. Systematics and Geography of Plants 70: 275-283.

LI, X. \& LI, R. (2016): Limnolyngbya circumcreta gen. \& comb. nov. (Synechococcales, Cyanobacteria) with three geographical (provincial) genotypes in China. - Phycologia 55: 478-491.

Mai, T.; Johansen, J.R.; Pietrasiak, N.; Bohunická, M. \& Martin, M.P. (2018): Revision of the Synechococcales (Cyanobacteria) through recognition of four families including Oculatellaceae fam. nov. and Trichocoleaceae fam. nov. and six new genera containing 14 species. - Phytotaxa 365: 1-59.

MAREŠ, J. (2018): Multilocus and SSU rRNA gene phylogenetic analyses of available cyanobacterial genomes, and their relation to the current taxonomic system. - Hydrobiologia 811: 19-34.

Mareš, J.; Johansen, J.R.; Hauer, T.; Zima JR, J.; Ventura, S.; Cuzman, O.; Tiribilli, B. \& KaštovskÝ, J. (2019): Taxonomic resolution of the genus Cyanothece (Chroococcales, Cyanobacteria), with a treatment on Gloeothece and three new genera, Crocosphaera, Rippkaea, and Zehria . - Journal of Phycology 55: $578-610$

Mareš, J.; StruneckÝ, O.; BuČínské, L. \& Wiedermannová, J. (2019): Evolutionary patterns of thylakoid architecture in Cyanobacteria. - Frontiers in Microbiology 10: article 277 (22 pages)

Nowicka-Krawczyk, P.; Mühlsteinová, R. \& \& Hauer, T. (2019): Detailed characterization of the Arthrospira type species separating commercially grown taxa into the new genus Limnospira (Cyanobacteria). - Scientific Reports 9: 1-11.

Mateo, P.; Perona, E.; Berrendero, E.; Leganés, F.; Martín, M. \& Golubic, S. (2011): Life cycle as a stable trait in the evaluation of diversity of Nostoc from biofilms in rivers. - FEMS Microbiology and Ecology 76: 185-198.

Martins, M.D. \& Branco, L.H.Z. (2016): Potamolinea gen. nov. (Oscillatoriales, Cyanobacteria): a phylogenetically and ecologically coherent cyanobacterial genus. - International Journal of Systematic and Evolutionary Microbiology 66: 3632-3641.

Martins, M.D.; Rigonato, J.; Taboga, S.R. \& Branco, L.H.Z. (2016): Proposal of Ancylothrix gen. nov., a new genus of Phormidiaceae (Cyanobacteria, Oscillatoriales) based on a polyphasic approach. - International Journal of Systematic and Evolutionary Microbiology 66: 2396-2405.

McGregor, G.B. \& Sendall, B.C. (2015): Phylogeny and toxicology of Lyngbya wollei (Cyanobacteria, Oscillatoriales) from north-eastern Australia, with a description of Microseira gen. nov. - Journal of Phycology 51: 109-119.

McGregor, G.B. \& Sendall, B.C. (2019): Potamosiphon australiensis gen. nov., sp. nov. (Oscillatoriales), a new filamentous cyanobacterium from subtropical 
north-eastern Australia. - Phytotaxa 387: 77-93.

Miscoe, L.H.; Johansen, J.R.; KocioleK, J.P. \& Lowe, R.L. (2016): The diatom flora and cyobacteria from caves on Kauai, Hawaii. I. Investigation of the cave diatom flora of Kanuai, Hawaii: an emphasis on taxonomy and distribution. - Bibliotheca Phycologica 123: 3-74.

Miscoe, L.H.; Johansen, J.R.; VACCARINO, M.A.; Pietrasiak, N. \& SHERwood, A.R. (2016): The diatom flora and cyobacteria from caves on Kauai, Hawaii. II. Novel cyanobacteria from caves on Kauai, Hawaii. - Bibliotheca Phycologica 123: 75-152.

Moro, I.; Di Bella, M.; Rascio, N.; La Rocca, N. \& ANDreoli, C. (2007): Conferva duplisecta Pollini: rediscovery in Euganean Thermal Springs (Italy) and new assignment to the Oscillatoria genus. - Caryologia 60: 133-136.

MüHLSTeinová, R.; Johansen, J.R.; PietrasiaK, N. \& Martin, M.P. (2014): Polyphasic characterization of Kastovskya adunca gen. nov. et comb. nov. (Cyanobacteria: Oscillatoriales), from desert soils of the Atacama Desert, Chile. - Phytotaxa 163: 216-228.

Nguyen, L.T.T.; Cronberg, G.; Moestrup, O. \& Daugbjerg, N. (2013): . Annamia toxica gen. et sp. nov.(Cyanobacteria), a freshwater cyanobacterium from Vietnam that produces microcystins: ultrastructure, toxicity and molecular phylogenetics. - Phycologia 52: 25-36.

NüBel, U.; Garcia-Pichel, F. \& Muyzer, G. (2000): The halotolerance and phylogeny of cyanobacteria with tightly coiled trichomes (Spirulina Turpin) and the description of Halospirulina tapeticola gen. nov., sp. nov. - International Journal of Systematic and Evolutionary Microbiology 50: 1265-1277.

Osorio-Santos, K.; Pietrasiak, N.; Bohunická, M.; Miscoe, L.H.; KovÁČIK, L.; Martin, M.P. \& JOHANSEN, J.H. (2014): Seven new species of Oculatella (Pseudanabaenales, Cyanobacteria): taxonomically recognizing cryptic diversification. - European Journal of Phycology 49: 450-470.

Palinska, K. A.; Thomasius, C. F.; Marquardt, J. \& Golubic, S. (2006): Phylogenetic evaluation of cyanobacteria preserved as historic herbarium exsiccate. - International Journal of Systematic and Evolutionary Microbiology 56: 2253-2263.

Perkerson, R.B.; Perkerson, E. \& Casamatta, D.A. (2010): Phylogenetic examination of the cyanobacterial genera Geitlerinema and Limnothrix (Pseudanabaenaceae) using 16S rDNA gene sequencing data. - Algological Studies 134: 1-16.

Perkerson, R.B.; Johansen, J.R.; KováČIK, L.; Brand, J.; KaštovskÝ, J. \& CASAMATTA, D.A. (2011): A unique pseudanabaenalean (cyanobacteria) genus Nodosilinea gen. nov. based on morphological and molecular data. - Journal of Phycology 47: 1397-1412.

Pietrasiak, N.; MÜHLSTeinOvá, R.; Siegesmund, M.A. \& Johansen, J.R. (2014): Phylogenetic placement of Symplocastrum (Phormidiaceae, Cyanophyceae) with a new combination S. californicum and two new species: S. flechtnerae and S. torsivum. - Phycologia 53: 529-541.

Rasoulouniriana, D.; Siboni, N.; Ben-Dov, E.; KramarskyWinter, E.; Loya, Y. \& Kushmaro, A. (2009): Pseudoscillatoria coralii gen. nov., sp. nov., a cyanobacterium associated with coral black band disease (BBD). - Diseases of Aquatic Organisms 87: 91-96.

ŘehákovÁ, K.; Johansen, J.R.; CaSAmatta, D.A.; Xuesong, L. \& VINCENT, J. (2007): Morphological and molecular characterization of selected desert soil cyanobacteria: three species new to science including Mojavia pulchra gen. et sp. nov. - Phycologia 46: 481-502

RIPPKA, R. \& COHEN-BAZIRE, G. (1983): The Cyanobacteriales: a legitimate order based on the type strain Cyanobacterium stanieri? - Annales de l'Institut Pasteur, Microbiologie 134B: 21-36.

Rippka, R.; Waterbury, J. \& Cohen-BAZire, G. (1974): A cyanobacterium which lacks thylakoids. - Archives for Microbiology 100: 419-436.

Rippka, R.; Deruelles, J.; Waterbury, J.B.; Herdman, M. \& STAINER, R.Y. (1979): Generic assignments, strain histories, and properties of pure cultures of Cyanobacteria. - Journal of General Microbiology 111: 1-61.

Sciuto, K. \& Moro, I. (2016): Detection of the new cosmopolitan genus Thermoleptolyngbya (Cyanobacteria, Leptolyngbyaceae) using the 16S rRNA gene and 16S-23S ITS region. -Molecular Phylogenetics and Evolution 105: 15-35.

Sciuto, K.; Moschin, E. \& Moro, I. (2017): Cryptic cyanobacterial diversity in the Giant Cave (Trieste, Italy): a new genus Timaviella (Leptolyngbyaceae). - Cryptogamie Algologie 38: 285-323.

Sciuto, K.; Andreoli, C.; Rascio, N.; La Rocca, N. \& Moro, I. (2012): Polyphasic approach and typification of selected Phormidium strains (Cyanobacteria). - Cladistics 28: 357-374.

Shalygin, S.; Shalygina, R.; Johansen, J.R.; Pietrasiak, N.; BerRendero GómeZ, E.; BoHUNiCKÁ, M.; MAREŠ, J. \& SHeIL, C.A. (2017): Cyanomargarita gen. nov. (Nostocales, Cyanobacteria): convergent evolution resulting in a cryptic genus. - Journal of Phycology 53: 762-777.

Siegesmund, M.A.; Johansen, J.R.; Karsten, U. \& Friedl, T. (2008): Coleofasciculus gen. nov. (Cyanobacteria): morphological and molecular criteria for revision of the genus Microcoleus Gomont. - Journal of Phycology 44: $1572-1585$.

Silva, C.S.P.; Genuario, D.; Vaz, M.G.M.V. \& Fiore, M. (2014): Phylogeny of culturable cyanobacteria from Brazilian mangroves. - Systematic and Applied Microbiology 37: $100-112$

SonG, G.-F.; JiAnG, Y.-G. \& LI, R.-H. (2015): Scytolyngbya timoleontis, gen. et sp. nov. (Leptolyngbyaceae, Cyanobacteria): a novel false branching Cyanobacteria from China. - Phytotaxa 224: 72-84.

STRUNeCKÝ, O.; BOHUNICKÁ, M.; JOHANSEN, J.R.; ČAPKOVÁ, K.; RAabová, L.; DvořÁK, P. \& KomÁreK, J. (2017): A revision of the genus Geitlerinema and a description of the genus Anagnostidinema gen. nov. (Oscillatoriophycidae, Cyanobacteria). - Fottea 17: 114-126.

StrunecKÝ, O.; KomÁREK, J. \& ŠMARDA, J. (2014): Kamptonema (Microcoleaceae, Cyanobacteria), a new genus derived from the polyphyletic Phormidium on the basis of combined molecular and cytomorphological markers. - Preslia 86: 193-207.

StruneckÝ, O.; Elster, J. \& KomáreK, J. (2010): Phylogenetic relationships between geographically separate Phormidium cyanobacteria: is there a link between north and south polar regions? - Polar Biology 33: 1419-1428.

TAton, A.; Wilmotte, A.; Šmarda, J.; Elster, J. \& KomÁReK, J. (2011): Plectolyngbya hodgsonii: a novel filamentous cyanobacterium from Antarctic lakes. - Polar Biology 34: 181-191.

Thu, N.K.; Tanabe, Y.; Yoshida, M.; Matsuura, H. \& Watanabe, 
M.M. (2012): Aerosakkonema funiforme gen. et sp. nov. (Oscillatoriales), a new gas-vacuolated oscillatorioid cyanobacterium isolated from a mesotrophic reservoir. - Phycologia 51: 672-683.

Turicchia, S.; Ventura, S.; Komárková, J. \& KomáReK, J. (2009): Taxonomic evaluation of cyanobacterial microflora from alkaline marshes of northern Belize. 2. Diversity of oscillatorialean genera. - Nova Hedwigia 89: $165-200$

Vaz, V.M.G.; GenuÁrio, D.B.; Andreote, A.P.; Malone, C.F.; Sant'Anna, C.L; Barbiero, L. \& Fiore, M.F. (2015): Pantanalinema gen. nov. and Alkalinema gen. nov.: novel pseudanabaenacean genera (Cyanobacteria) isolated from saline-alkaline lakes. - International Journal of Systematic and Evolutionary Microbiology 65: 298-308.

VÁzQueZ-MartíneZ, J.; GutierReZ-VillagomeZ, J.M.; Fonseca-García, C.; Ramírez-Chávez, E.; Mondragón-SÁNCheZ, M.L.; PARTIDA-Martínez, L.; Johansen, J.R. \& Molina-Torres, J. (2018): Nodosilinea chupicuarensis sp. nov. (Leptolyngbyaceae, Synechococcales) a subaerial cyanobacterium isolated from a stone monument in central Mexico. - Phytotaxa 334: 167-182.

Vinogradova, O.; Mikhailyuk, T.; Glaser, K.; Holzinger A. \& Karsten U. (2017): New species of Oculatella (Synechococcales, Cyanobacteria) from terrestrial habitats of Ukraine. - Ukrayins'kyi Botanichnyi Zhurnal 74: 509-520.

Walter, J.M.; Coutinho, F.H.; Dutilh, B.E.; Swings, J.;
ThOmPson, F.L. \& ThOMPSOn, C.C. (2017): Ecogenomics and Taxonomy of Cyanobacteria Phylum. - Frontiers in Microbiology 8: 2132.

Zammit, G.; Billi, D. \& Albertano, P. (2012): The subaerophytic cyanobacterium Oculatella subterranean (Oscillatoriales, Cyanophyceae) gen.et sp. nov.: a cytomorphological and molecular description. - European Journal of Phycology 47: 341-354.

Zimba, P.V.; HuANG, I.S.; Foley, J.E. \& Linton, E.W. (2017): Identification of a new-to-science cyanobacterium, Toxifilum mysidocida gen. nov. \& sp. nov. (Cyanobacteria, Cyanophyceae). - Journal of Phycology 53: 188-197.

Supplementary material

The following supplementary material is available for this article:

Table S1. Review of cyanobacteria 2019.

This material is available as part of the online article (http:/ fottea.czechphycology.cz/contents)

(C) Czech Phycological Society (2020)

Received September 13, 2019

Accepted November 25, 2019 